\title{
Evaluating the financial efficiency of energy and water saving installations in passive house
}

\author{
Agnieszka Stec $^{1, *}$, Aleksandra Mazur ${ }^{1}$ and Daniel Słyś ${ }^{1}$ \\ ${ }^{1}$ Department of Infrastructure and Sustainable Development, Rzeszow University of Technology, al. \\ Powstańców Warszawy 6, 35-959 Rzeszów, Poland
}

\begin{abstract}
The article contains the outcomes of the Life Cycle Cost analysis for alternative energy and water sources utilized in passive buildings. The solutions taken into account included: heat pumps, solar collectors, photovoltaic panels, Drain Water Heat Recovery units, Rain Water Harvesting Systems and Greywater Recycling Systems. In addition, air pollution emission reduction was also calculated for all the installation variants analyzed. The analysis have shown that the systems under consideration could serve as alternatives for traditional installations. Their use has resulted in reductions in the consumption of fossil fuels and natural water resources, thus contributing to environmental improvements.
\end{abstract}

\section{Introduction}

The observable economy growth in several countries over the last few years have resulted in improved life quality, reduced poverty as well as increased aspirations and expectations. These factors have together with increased populations led to the over exploitation of natural resources and growing emissions [1]. The forecasts are that such trends will persist into the future if no suitable actions are taken [2]. The issue of climate change, as an outcome of both natural and anthropogenic factors, cannot be overlooked [3, 4]. The observed enormity of the damaging impacts of the changes emphasizes the significance of steps, aimed at minimizing the exploitation of non-renewable resources [5]. Since one of the largest global consumer of energy is the civil engineering sector $[6,7]$, the quest for efficient and cheap technologies that enable reductions in water and energy consumption by the sector has become significant [8]. Developments in energy-saving constructions in recent years such as the passive or zero energy have effected changes in the share of various components of energy consumption in buildings and consequently contributed to significant increases in demand for energy for water heating purposes $[9,10]$. Reductions in the amount of energy derivable from fossil fuels has become possible due to the application of solutions that make use of renewable sources of energy, especially solar and waste [11-13] .

A key aspect of sustainable construction, besides all measures aimed at reducing the amount of energy needed for general as well as water heating, is the limitation of tap water use [14]. This is an accomplishable step through the use of alternative sources of water such

${ }^{*}$ Corresponding author: stec_aga@prz.edu.pl 
as the use of rainwater and graywater sources [15-17]. Such models for managing water resources of varied quality parameters is compatible with contemporary requirements for water and sewage economy that is being implemented in accordance with the principles of sustainable development. With the awareness of the magnitude of the issue at stake, studies aimed at ascertaining the profitability of the application of systems that enable reductions in demand for tap water as well as energy both for general and water heating in passive buildings were undertaken. As a result of the prevailing climatic conditions in Poland, heating systems, example gas boilers, for passive house are most often designed for use of conventional sources of energy. Passive house besides being designed to ensure a comfortable microclimate indoors, ought to be economical both in terms construction and in exploitation since this guarantees possibilities of popularising the conceptual standards for passive house construction while attracting the attention of potential investors. Consequently, an effective financing was determined for standard passive house in Poland, including for similar buildings fitted with devices for minimizing energy and water consumption through the use of alternative solutions such as solar panels, photovoltaic panels, heat pumps, graywater recycling system, rainwater harvesting system and Drain Water Heat Recovery unit. Reductions in emissions of pollutants accruing to the use of renewable sources of Energy were also calculated for each of the installation variants covered by the study.

\section{Methodology}

The Life Cycle Costs methodology was chosen as the tool for the financial analysis. $L C C$ costs for the variants of installation analyzed are based on the formula (1). This methodology allowed to take into account all the costs connected with investment (INV) and use of a system $\left(O C_{t}\right)$ and the residual value $(R V)$. However, according to the guidelines in the work [18] in justified cases when the life of the system exceeds the length of the period of analysis, the residual value can be omitted. Taking this into account and the assumed lengths of the $L C C$ analysis, the $R V$ value was not considered.

$$
L C C=I N V+\sum_{t=1}^{T}(1+r)^{-t} \cdot O C_{t}+R V
$$

where:

$I N V$ - investments, €;

$O C_{t}$ - operating costs in the year $t, €$;

$R V$ - residual value, $€$;

$T$ - duration of the $L C C$ analysis, years;

$r$ - constant discount rate;

$t$ - another year of the system use.

Exploitation costs that result from Energy uses for purpose of heating water and living space as well as the associated polluting emissions were, for all the investment variants covered by the study, determined using the ArCADia-TERMO 6.6 software. While the simulation model described in [19] was applied for calculations in all variants using rainwater harvesting systems, the model described in the publication [20] used waste water heat recovery system in all the variants. 


\section{Case Study}

The object of the study is a detached, family residential building located in Rzeszów, south-east Poland. The building has two floors above ground level with a total usable surface area of $138 \mathrm{~m}^{2}$. The building in question meets all the requirements stipulated by the German Passivhaus Institut in Darmstadt (PHI) for all constructions erected in passive standards. The building had a system of mechanical inflow-exhaust ventilation with heat recuperation installed. The building also envisaged the installation of underfloor heating system due to the prevailing climatic conditions in Poland. The heating capacity requirement of the building, amounting to $4.4 \mathrm{~kW}$ was determined based on the PNEN12831standards [21]. The heat capacity needed for heating utility hot water, which ranged from 3.2 to $9.2 \mathrm{~kW}$ depending on the adopted number of residents and on the daily demand for hot water per person was also determined.

In order to obtain maximum efficiency of the installed non-conventional systems in the analysed building, studies were conducted for several investment options that involves varied combinations of the solutions. Installation arrangements for a few selected options are illustrated in the charts.

- Variant 0 - traditional installation with a dual-functional gas boiler supplied with water from public networks and its sewerage and rainwater discharged through the drains.

- Variant 1 - installation with underground heat pump and solar collectors supplied with water from public networks and its sewerage and rainwater discharged through the drains.

- Variant 2 - installation with underground heat pump and solar collectors supplied with water from public networks, fitted with a system for use of rainwater and its sewerage discharged through the drains (Fig. 1).

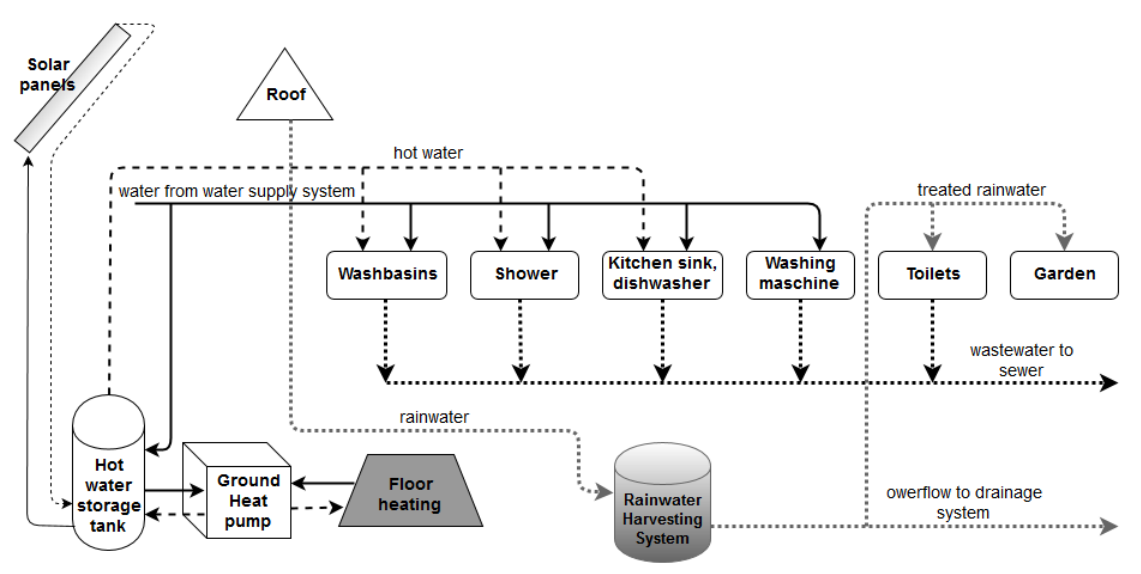

Fig. 1. The solution of installation in Variant 2.

- Variant 3 - installation with underground heat pump and solar collectors supplied with water from public networks, equipped with a system for recycling greywater and its sewerage and rainwater discharged through the drains.

- Variant 4 - installation with air heat pump and photovoltaic panels supplied with water from public networks and its sewewrage and rainwater discharged through the drains.

- Variant 5 - installation with air heat pump and photovoltaic panels supplied with water from public networks, equipped with a system for using rainwater and its sewerage discharged through the drains. 
- Variant 6 - installation with air heat pump and photovoltaic panels supplied with water from public networks, equipped with a system for recycling greywater and its sewerage and rainwater discharged through the drains (Fig. 2).

- Variant 7 - installation with dual-functional gas boiler supplied with water from public networks, equipped a system for heat recovery from waste water and a system for recycling greywater and its sewerage and rainwater discharged through the drains (Fig. 3).

- Variant 8 - installation with dual-functional gas boiler supplied with water from public networks, equipped with a system for recovering heat from waste water and its sewerage and rainwater discharged through the drains.

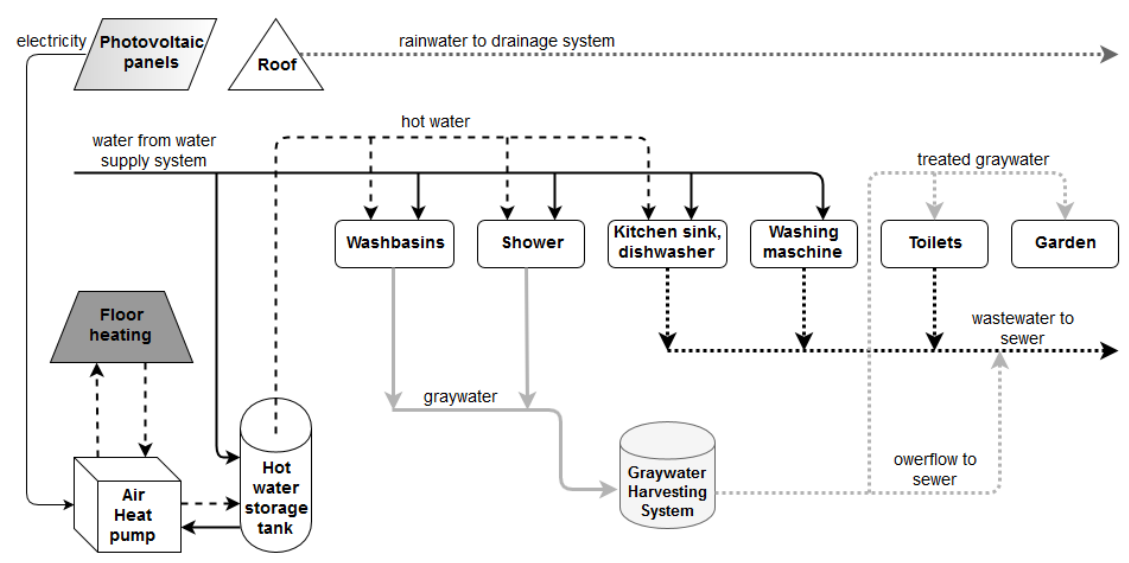

Fig. 2. The solution of installation in Variant 6.

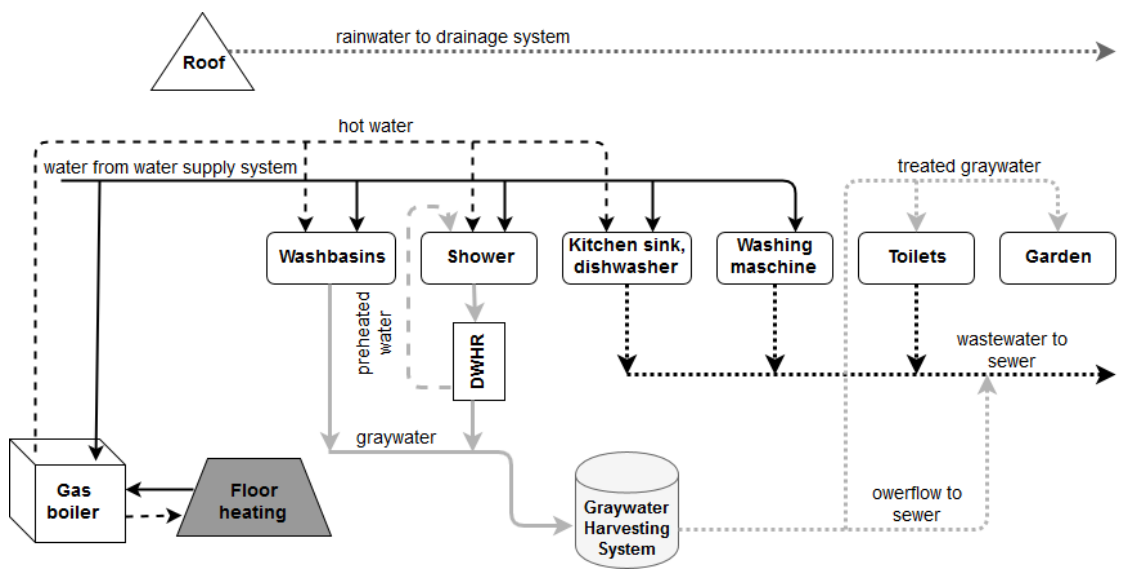

Fig. 3. The solution of installation in Variant 7.

The study uses parameter values presented in table 1 to enable it determine the annual water and energy needs, resulting from the exploitation of analyzed installation options. In order to reflect their impacts on the eficiency of the financial investments involved, calculations concerning varied combinations of duration of using the shower, and varied number of users, which in turn affect the volume of water consumption and amount of discharged waste water in each variant were done.

The profitability analysis for each of the installation variants exploited in the building understudied was carried out and present in table 2. The unit cost price for water, electricity, gas, including the cost of discharging sewage, and rainwater through the drains 
was established based on current prices set by the relevant Municipal Companies in Rzeszów. Investment costs were, on the other hand, calculated relying on prices provided by producers of various systems and components of the analysed installations.

Table 1. Key data adopted for the calculations.

\begin{tabular}{|c|c|}
\hline Parameter & Parameter value \\
\hline Daily water consumption for green areas watering & $1.25 \mathrm{~L} / \mathrm{m}^{2} /$ day \\
\hline Daily water consumption for toilet flushing & $35 \mathrm{~L} /$ person/day \\
\hline Daily water consumption in washbasins & $12 \mathrm{~L} /$ person/day \\
\hline Daily water consumption in washing machine & $16 \mathrm{~L} /$ person/day \\
\hline Hot water temperature & $55^{\circ} \mathrm{C}$ \\
\hline Mixed water flow from the showerhead & $7 \mathrm{dm}^{3} / \mathrm{min}^{2}$ \\
\hline Roof area & $125 \mathrm{~m}^{2}$ \\
\hline Shower length $l_{\text {sh }}$ & $5,8,12 \mathrm{~min} /$ person $/$ day \\
\hline Surface of green areas & $300 \mathrm{~m}$ \\
\hline The number of occupants $O_{c}$ & $3,4,5$ persons \\
\hline
\end{tabular}

Table 2. Data used in the calculation of $L C C$ costs.

\begin{tabular}{|c|c|}
\hline Parameter & Parameter value \\
\hline Analysis period $T$ & 20 years \\
\hline The annual increase in electricity prices & $4 \%$ \\
\hline The annual increase in gas prices & $5 \%$ \\
\hline $\begin{array}{c}\text { The annual increase in the prices of purchase of water from the water- } \\
\text { pipe network }\end{array}$ & $6 \%$ \\
\hline $\begin{array}{c}\text { The annual increase in the prices of rainwater discharge } \\
\text { to the sewage network }\end{array}$ & $4 \%$ \\
\hline $\begin{array}{c}\text { The annual increase in the prices of sanitary sewage discharge } \\
\text { to the sewage system }\end{array}$ & $6 \%$ \\
\hline The cost of purchasing electricity in the year 0 & $0.133 € / \mathrm{kWh}$ \\
\hline The cost of purchasing water from the water-pipe network in the year 0 & $1.04 € / \mathrm{m}^{3}$ \\
\hline The cost of sanitary sewage discharge to sewage network in the year 0 & $0.894 € / \mathrm{m}^{3}$ \\
\hline The cost of discharge of rainwater to the sewage network in the year 0 & $0.719 € / \mathrm{m}^{3}$ \\
\hline The cost of purchasing gas in the year 0 & $0.471 € / \mathrm{m}^{3}$ \\
\hline The discount rate $r$ & $5 \%$ \\
\hline
\end{tabular}

\section{Results and discussion}

The results of the study, presented in table 3 have made it possible to specify the most financially benefitting installation variant, whose installation in the analyzed building would enable the achievement of the highest energy and water savings. The LCC values obtained indicate that the variant is, from all the instances considered, the option in which air heat pump powered with electric energy from photovoltaic panels as well as rainwater harvesting system (Varant 5). The exception was in two cases in which the installation was exploited by 3 people, while the showering time lasted 5 or $8 \mathrm{~min} /$ person/day. The most financially benefitting option is, in such circumstances, the variant 6 in which alternative 
source of water namely, recycling of greywater was applied. Despite the fact that the variant was associated with more than 2.5-fold higher financial inputs $I N V$ than variant 0 , the savings attained during its exploitation made the exploitation costs $O C_{t}$ to be almost 3fold lower when compared to variants in which traditional system solutions were applied. The use of air heat pumps powered with energy from photovoltaic panels resulted in reductions in annual energy needs for heating water and living spaces by as much as $90 \%$ than from external networks. It was observed that the difference between the $L C C$ values for both variants 5 and 6 was insignificant which offers room for choice depending on the investor's preferences regarding the use of alternative sources namely, greywater or rainwater.

Table 3. Results of calculations.

\begin{tabular}{|c|c|c|c|c|c|c|c|c|c|c|}
\hline \multirow{11}{*}{ 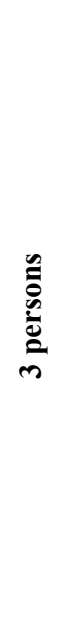 } & \multirow{2}{*}{ 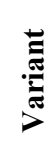 } & \multicolumn{3}{|c|}{$l_{s h}=5 \mathrm{~min} /$ person $/$ day } & \multicolumn{3}{|c|}{$l_{s h}=8 \mathrm{~min} /$ person $/$ day } & \multicolumn{3}{|c|}{$l_{s h}=12 \mathrm{~min} /$ person $/$ day } \\
\hline & & $\begin{array}{c}I N V \\
€\end{array}$ & $\underset{€}{O C_{t}}$ & $\underset{€}{L C C}$ & $\begin{array}{c}I N V \\
€\end{array}$ & $\underset{€}{O C_{t}}$ & $\underset{€}{L C C}$ & $\begin{array}{c}I N V \\
€\end{array}$ & $\underset{€}{O C_{t}}$ & $\underset{€}{L C C}$ \\
\hline & 0 & 5080 & 16730 & 21810 & 5115 & 19366 & 24481 & 5115 & 22918 & 28033 \\
\hline & 1 & 14004 & 13719 & 27723 & 16008 & 14827 & 30835 & 16328 & 17164 & 33491 \\
\hline & 2 & 15498 & 11488 & 26986 & 17502 & 12596 & 30099 & 17983 & 14933 & 32916 \\
\hline & 3 & 17107 & 9774 & 26881 & 19111 & 10940 & 30052 & 19776 & 13301 & 33077 \\
\hline & 4 & 11465 & 8876 & 20341 & 11488 & 9838 & 21326 & 12186 & 11158 & 23344 \\
\hline & 5 & 12960 & 6645 & 19604 & 12983 & 7607 & 20589 & 13841 & 8927 & 22768 \\
\hline & 6 & 14569 & 4930 & 19499 & 14592 & 5951 & 20543 & 15634 & 7318 & 22952 \\
\hline & 7 & 8885 & 12278 & 21163 & 8919 & 14237 & 23156 & 9264 & 17239 & 26503 \\
\hline & 8 & 5781 & 16224 & 22005 & 5816 & 18124 & 23939 & 5816 & 21102 & 26917 \\
\hline & 0 & 5115 & 19950 & 25065 & 5115 & 23485 & 28600 & 5225 & 28205 & 33430 \\
\hline & 1 & 16008 & 15483 & 31491 & 16328 & 18328 & 34655 & 17381 & 20240 & 37621 \\
\hline & 2 & 17502 & 13182 & 30684 & 17822 & 16027 & 33849 & 19167 & 17939 & 37106 \\
\hline$气$ & 3 & 19111 & 11578 & 30690 & 19431 & 14468 & 33899 & 20960 & 16419 & 37379 \\
\hline 离 & 4 & 11716 & 10740 & 22457 & 12414 & 12043 & 24457 & 13029 & 13786 & 26815 \\
\hline 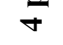 & 5 & 13210 & 8440 & 21650 & 13908 & 9743 & 23651 & 14684 & 11486 & 26169 \\
\hline & 6 & 14820 & 6836 & 21656 & 15517 & 8183 & 23700 & 16477 & 9965 & 26442 \\
\hline & 7 & 8919 & 14994 & 23914 & 8919 & 18000 & 26919 & 9374 & 21993 & 31367 \\
\hline & 8 & 5816 & 18899 & 24714 & 5816 & 21860 & 27676 & 5926 & 25814 & 31739 \\
\hline & 0 & 5115 & 23170 & 28285 & 5225 & 27592 & 32817 & 5225 & 33489 & 38714 \\
\hline & 1 & 16328 & 17655 & 33983 & 17381 & 20637 & 38019 & 18226 & 24185 & 42411 \\
\hline & 2 & 17822 & 15059 & 32881 & 18875 & 18041 & 36917 & 19881 & 21589 & 41470 \\
\hline & 3 & 19431 & 13793 & 33224 & 20485 & 16817 & 37301 & 21674 & 20406 & 42080 \\
\hline$\frac{m}{2}$ & 4 & 12414 & 12605 & 25019 & 13256 & 14237 & 27493 & 13781 & 16413 & 30193 \\
\hline$n$ & 5 & 13908 & 10009 & 23917 & 14750 & 11641 & 26391 & 15436 & 13816 & 29252 \\
\hline & 6 & 15517 & 8743 & 24260 & 16360 & 10416 & 26776 & 17229 & 12633 & 29862 \\
\hline & 7 & 8919 & 18017 & 26936 & 9029 & 21763 & 30793 & 9374 & 26744 & 36119 \\
\hline & 8 & 5816 & 21880 & 27695 & 5926 & 25584 & 31510 & 5926 & 30524 & 36450 \\
\hline
\end{tabular}


The highest $L C C$ index value was obtained in variants where underground heat pump worked in association with slar collectors, Variant 1, Variant 2, Variant 3. This is mainly due to the initial high investment costs, which are not compensated for by energy saves during the 20-year period of exploitation. The exploitation of options could limit annual energy concumption by as much as $34-49 \%$, depending on the number of persons and level of hot water consumption. The little reduction in energy needs in comparison with variants with photovoltaic panels is primarily due to the large variability of sunshine prevailent in Polish climatic conditions during the year, which calls for necessity to use substantial amount of energy from external public power supply networks during the autumn and winter periods. However, if the three variants were compared based on their limited demand for water from public supplies the more favourable, assuming the system is used by three individuals with the $q_{s h}=5 \mathrm{~min} /$ person/day or $q_{s h}=8 \mathrm{~min} /$ person/day, turned out to be Variant 3 which uses recycled greywater, while Variant 2 which uses rainwater harvesting system proved to be better in all other cases.

Results of calculations for variants 7 and 8 , which use waste water heat recovery through the installation of Drain Water Heat Recovery unit at the shower's outlet have shown that they are more profitable than variant 0 if the shower is used by 3 persons and does not last longer than 5 minutes. Increased hot water uses due to extensions of bathing duration and increased number of residents results in greater amount of energy being recovered from waste water and in consequence increased financial efficiency of investments. Variant 7, which uses greywater recycling system besides the DWHR unit is more benefitting financially. The application of waste water heat recovery system in the analyzed building limits annual energy needs for hot water heating, which in the case being considered was only $9-17 \%$.

The assumptions for a passive building is that it is environmentally friendly, which is why ecological, besides economical criteria should be taken care of while deciding the installation system. It was observed, in course of analyzing pollutant emissions, that Variants 4,5 and 6 had the least environmental impact. This being due to the fact that the energy needs of such buildings are met without resorting to fossil fuels as the electricity needed to power the heat pumps and ancillary equipment is supplied by photovoltaic panels. The DWHR heat exchanger applied in Variants 7 and 8 has enabled the reduction of annual carbon dioxide emissions by about $8-16 \%$ compared to Variant 0 , depending on the of residents and amount of hot water consumption. Much better results were obtained in Variants 1, 2 and 3, where $\mathrm{CO}_{2}$ emissions were reduced to $14-29 \%$ compared to Variant 0 thanks to the use of solar collectors and underground heat pumps.

\section{Conclusion}

The analyses have indicated the appropriateness of use of Life Cycle Cost (LCC) methodology for assessing investment projects, and could the choice of the most financially viable option. Reliance on the level of initiation investment costs, as it is currently practiced in majority of cases in Poland can lead to the choice of variants that would generate high costs of operation in the long-run. This was corroborated by studies conducted in family homes, where alternative water and energy sources were applied. Although the variant with traditional installations (Variant 0) was characterized by the least financial engagement, its operating costs calculated for all instances significantly exceded similar costs for unconventional installation options. The lowest level of LCC index was, in majority of the cases considered, obtained in the variant in which the energy needed of central and water heating was sourced from air heat pumps driven by electricity from photovoltaic panels, while alternative source of water for non-potable uses was rainwater (Variant 5). The use 
of this source of energy in the passive building being analyzed contributed to reductions in annual $\mathrm{CO}_{2}$ emissions by over $95 \%$ compared to Variant 0 .

The studies have indicated that the use of heat pumps, solar collectors and panels as well as rain water and greywater can have significant impacts on reducing energy and drinkable water consumption in family homes. Their application would therefore contribute to limiting the exploitation of fossil sources for energy purposes, including natural water resources, thus leading to improved state of the natural environment.

\section{References}

1. S. Manju, N. Sagar. Renewable and Sustainable Energy Reviews 73, 594-609 (2017)

2. Ş. Kılkış. J. Clean. Prod. 130, 222-234 (2016)

3. D.I. Stern, R.K. Kaufmann. Climatic Change 122, 257-269 (2014)

4. B. Kaźmierczak, A. Kotowski. Theor. Appl. Climatol. 118, 285-296 (2014)

5. A. Figueiredo, J. Figueira, R. Vicente, R. Maio. Build. Environ. 103, 276-288 (2016)

6. L. Pérez-Lombard, J. Ortiz, C. Pout. Energ. Buildings 40, 394-398 (2008)

7. K. Sperling, B. Möller. Appl Energy 92, 831-842 (2012)

8. A. Figueiredo, J. Kämpf, R. Vicente. Energ. Buildings 118, 181-196 (2016)

9. J. Schnieders, W. Feist, L. Rongen. Energ. Buildings 105, 71-87 (2015)

10. A.J. Marszal, P. Heiselberg, J.S. Bourrelle, E. Musall, K. Voss, I. Sartori, A. Napolitano. Energ. Buildings 43, 971-979 (2011)

11. J. Rekstad, M. Meir, E. Murtnes, A. Dursun. Energ. Buildings 96, 149-161 (2015)

12. Directive 2010/31/EU of the European Parliament and of the council of 19 May 2010 on the energy performance of buildings (recast). J. Eur. Union, 13-35 (2010)

13. Ramadan, M., Lemenand, T., Khaled, M., 2016. Energ. Buildings 128, 575-582.

14. K. Urbaniec, H. Mikulčić, N. Duić, R. Lozano. J. Clean. Prod. 130, 1-11 (2016)

15. A. Stec, S. Kordana. Resour. Conserv. Recy. 105, 84-94 (2015)

16. G. Markovič, D. Káposztásová, Z. Vranayová. Transactions on Environment and Development 10, 242-249 (2014)

17. D. Słyś, A. Stec. Ecol. Chem. Eng. S 21, 623-635 (2014)

18. Life Cycle Cost Handbook. Guidance for Life Cycle Cost Estimation and Analysis. Office of Acquisition and Project Management, U.S. Department of Energy, Washington.

Available: www.energy.gov/sites/prod/files/2014/10/f18/LCC\%20Handbook\%20Final\%20Versio n\%209-30-14.pdf (accessed February 2017).

19. D. Słyś. Water Environ. J. 23, 318-325 (2009)

20. S. Fidewicz. Biblioteka Źródłowa Energetyki Prosumenckiej. Available: www.klaster3x20.pl

21. PN-EN 12831. Heating systems in buildings. Method for calculation of the design heat load (2006) 